\title{
Meeting the world's demand for safe assets? Macroeconomic policy and the international status of the euro after the crisis
}

European Journal of International Relations $|-3|$

(C) The Author(s) 2017

Reprints and permissions: sagepub.co.uk/journalsPermissions.nav DOI: $10.1177 / 1354066117744030$ journals.sagepub.com/home/ejt

@SAGE

\section{Mattias Vermeiren}

Ghent University, Belgium

\begin{abstract}
In this article, I engage with the chartalist literature to explore the political foundations of international currencies. Drawing on this literature as well as on recent scholarship on the shortage of safe assets in the world economy, I challenge a prevailing premise of the International Political Economy literature that international currency status needs to be based on conservative macroeconomic policy institutions and practices, which is deemed necessary to maintain foreign confidence in the stability of the real value of the international currency. I contend that international currency status in the post-crisis world economy hinges on the willingness and capacity of the currency provider to adopt accommodating monetary and fiscal policies. First, the central bank needs to offer a backstop to the market for sovereign debt securities by acting as a lender of last resort to the government, whereas fiscal policy expansion is necessary to sufficiently expand the stock of the only securities that can assume the function of genuinely safe assets: sovereign debt. Second, expansionary monetary and fiscal policies enable the international currency issuer to supply safe assets to the rest of the world by running deficits on its trade balance. This article analyses how the European Central Bank's monetary policy decisions in the wake of the crisis ran against these two prerequisites, constraining the Eurozone to become a large net provider of safe assets in the world economy. By linking these decisions to the creditor and export interests of the Northern Eurozone countries, it disputes the European Central Bank's 'neutral stance' regarding the internationalization of the euro.
\end{abstract}

\section{Keywords}

Crisis, dollar, euro, European Central Bank, fiscal policy, monetary policy

\footnotetext{
Corresponding author:

Mattias Vermeiren, Ghent University, Universiteitstraat 8, Gent, 9000, Belgium.

Email: mattias.vermeiren@ugent.be
} 


\section{Introduction}

A nation's international monetary power is intrinsically linked to the extent of crossborder usage of its currency: the highly uneven international distribution of monetary power mostly derives from the highly hierarchical structure of the global monetary system in terms of currency internationalization (e.g. Andrews, 2006; Chey, 2012; Helleiner and Kirshner, 2009). Cohen (1998: 114) characterized this hierarchical structure as a 'currency pyramid' — 'narrow at the top, where a few popular currencies circulate; increasingly broad below, reflecting varying degrees of competitive inferiority'. The eruption of the global financial crisis in 2008 has left this hierarchical structure of the global monetary system mostly intact. Table 1 shows that the dollar continues to be the top currency in international finance, whereas the euro remains a distant second, when we look at the shares of these two currencies in foreign exchange reserves, international debt securities, loans and deposits. Yet, despite the institutional deficiencies of the Economic Monetary Union (EMU) laid bare by the crisis, the euro continues to be the most important rival of the dollar in international currency competition. Furthermore, the crisis pushed the Eurozone countries to implement substantial reforms to make the euro sustainable in the longer term. As Helleiner (2015: 234) notes, 'If these [reforms] are successful and the Eurozone became an "embedded" currency area, the euro's capacity to grow as an international currency would be bolstered considerably'.

By drawing on chartalist insights and recent scholarship on the scarcity of 'safe assets' in the global economy, I argue that the EMU's reforms and changes in its monetary and fiscal policy institutions and policies have been too restrictive to boost the international role of the euro. My argument contradicts a central hypothesis in the literature on currency internationalization, which states that relatively conservative monetary and fiscal policies are a prerequisite for establishing and maintaining international currency leadership by bolstering foreign confidence in the stability of the currency (e.g. Chey, 2012; Helleiner and Kirshner, 2009; Walter, 2006). In this regard, the Eurozone's relatively

Table I. Share of euro/US dollar in international finance.

\begin{tabular}{lccccccc}
\hline & 2003 & 2005 & 2007 & 2009 & 2011 & 2013 & 2015 \\
\hline Forex reserves & & & & & & & \\
Euro & 22.6 & 22.6 & 21.1 & 22.7 & 21.9 & 20.7 & 19.9 \\
US dollar & 68.5 & 68.2 & 69.6 & 67.3 & 65.9 & 65.6 & 64.1 \\
International debt securities & & & & & & & \\
Euro & 28.7 & 29.5 & 27.6 & 26.4 & 23.2 & 21.4 & 22.7 \\
US dollar & 45.6 & 45.2 & 48.5 & 50.5 & 54.5 & 58.8 & 60.3 \\
International loans & & & & & & & \\
Euro & 25.2 & 25.1 & 23.8 & 24.3 & 25.2 & 22.0 & 21.9 \\
US dollar & 54.1 & 54.7 & 54.4 & 55.8 & 54.8 & 56.3 & 57.7 \\
International deposits & & & & & & & \\
Euro & 27.8 & 26.5 & 21.5 & 22.9 & 24.4 & 22.9 & 24.8 \\
US dollar & 52.2 & 53.9 & 58.5 & 58.0 & 58.4 & 57.9 & 56.5 \\
\hline
\end{tabular}

Source: European Central Bank. 
orthodox macroeconomic policy regime - consisting of a conservative central bank with a single mandate to fight inflation and rules imposing limits on national fiscal deficit and public debt levels - is usually seen as an attractive feature of the euro as an international currency (Chinn and Frankel, 2008; Helleiner, 2008). Taking into account the importance of safe assets for the liquidity and stability of the international monetary and financial system, it can be reasonably assumed that the issuer of the international currency needs be the largest net seller of safe assets in the global political economy. This raises the question: are relatively accommodative or conservative macroeconomic policies most conducive to this role?

Making use of chartalist views on how the safety of assets depends on a backstop provided by the state's power to create 'outside money', I argue that in the context of the global safe asset shortage, international currency leadership depends on relatively accommodating macroeconomic policies. First, these policies are needed to create safe assets: fiscal deficits are necessary to sufficiently expand the stock of sovereign bonds, which are the only debt securities that can be fully backed by the central bank's power to create outside money. Second, expansionary monetary and fiscal policies enable the international currency issuer to provide safe assets to the rest of the world: these policies bolster domestic demand and lead to deficits on its current account balance, which is essential for being a large net international seller of safe assets.

These insights imply that the EMU's macroeconomic policy institutions and policies remain ill-equipped to allow the region to meet the world's demand for safe assets. In the following, I show how changes in the Eurozone's monetary and fiscal policy institutions and policies in response to the crisis constrain its ability to become a net supplier of eurodenominated safe assets to the world economy. More specifically, I draw attention to the role of the European Central Bank's (ECB's) monetary policy in moving the Eurozone's current account balance towards a significant surplus since the crisis, as a result of which the region became a large net purchaser of safe assets from the rest of the world: its decisions on when and how to produce and allocate outside money to private banks and governments — by determining the eligibility criteria for its liquidity injections and controlling the launch and structure of its asset purchase programmes - favoured the credit and export interests of the northern trade surplus countries by allowing them to deflect the burden of macroeconomic adjustment onto the peripheral deficit counties. Moreover, I argue that these decisions were not imposed on the ECB by the restrictive monetary and fiscal policy rules of the Treaty on the Functioning of the European Union (TFEU) and the associated need to avoid fiscal transfers between the Eurozone governments: while the ECB might have been concerned about the potential fiscal implications of its liquidity facilities and asset purchases programmes and the contestation of these programmes in northern countries like Germany, they reflect an unduly restrictive interpretation of the TFEU. Given how its discretionary monetary policy decisions have constrained the ability of the Eurozone to be a large net international provider of safe assets, the self-proclaimed 'neutral stance' of the ECB regarding the euro's internationalization (i.e. neither hindering nor promoting the international role of the euro) should be disputed.

In order to elaborate these arguments, the article will proceed as follows. In the next section, I review the key characteristics of international currencies and explain the continuing resilience of the US dollar by the global safe asset shortage. Moreover, I discuss 
the political foundations of safe assets by drawing on chartalist understandings of money, considering several reasons why the lack of political integration in the Eurozone reduces the attractiveness of its sovereign bonds as global safe assets compared to US treasuries. In the subsequent section, I argue that the lack of a relatively accommodative monetary and fiscal policy nexus is the most important reason; here, I offer several theoretical arguments as to why the international currency issuer has to pursue accommodative macroeconomic policies in order to be a large net international seller of safe assets. In the section thereafter, I show how the EMU's macroeconomic policy institutions have constrained the region's role as a safe asset provider; here, I focus on how the ECB's monetary policy decisions, which were based on an overly restrictive interpretation of the TFEU rules, favoured the creditor and export interests of the northern countries. By stressing the importance of a relatively accommodative monetary and fiscal policy nexus for international currency leadership, I conclude that the political constraints to the international status of the euro go beyond the lack of fiscal union in the Eurozone.

\section{International currencies as safe assets: Political foundations}

Liquidity and stability are two essential functions of international currencies in the world economy: international currencies should be available in the form of sufficient amounts of assets that can be bought and sold in large quantities without affecting their price and undermining confidence in their stability. Taking these two functions into consideration, the pre-crisis literature on international currencies identified two essential preconditions for currency internationalization (for a recent review of the literature, see Chey, 2012). First, foreigners need to have confidence in the currency's stable value, which was usually interpreted as an absence of excessive inflation and exchange rate volatility. Second, the currency needs to be backed by open, deep and liquid financial markets that offer foreigners a wide range of financial securities. The central predicament of international currency leadership is that these two prerequisites can clash with each other: by providing a high amount of liquid assets to foreigners, the issuer of the international currency needs to accumulate foreign liabilities to such an extent that foreign confidence in its stability can be undermined. Before the crisis, many observers believed that the stability and hegemony of the US dollar was put at risk by such a 'Triffin dilemma': while the US had a unique capacity to sell US dollar-denominated assets due to the centrality of the US financial system in the world economy, they argued that the resulting overhang of US dollar liabilities would weaken foreign confidence in the stability of the US dollar by putting downward pressure on its nominal exchange rate (e.g. Eichengreen, 2007).

The global financial crisis showed that these concerns were overblown: despite the fact that the crisis originated in the US financial system, the dollar did not crash and even appreciated at the height of the crisis. From the perspective of recent literature in macrofinancial economics, the persistence of the US dollar as the world's dominant international currency can be explained by a shortage of 'safe assets' in the contemporary world economy (Caballero et al., 2008; Gorton et al., 2012; Gourinchas and Jeanne, 2012). The concept of safe assets merges the 'stability' and 'liquidity' prerequisites of international currency status: they are liquid 'information-insensitive' debt securities that have no credit and default risk and whose nominal repayment is therefore certain. These assets 
are the 'cornerstone' of the international financial system, as the International Monetary Fund (IMF, 2012: 81) argued in its 2012 Global Financial Stability Report: 'Safe assets have variable functions in global financial markets, including as a store of value, collateral in repurchase and derivatives markets, key instruments in fulfilling prudential requirements and pricing benchmarks'. Three international developments have generated a global imbalance of the demand over supply of safe assets. First, the growth in foreign exchange reserves, which swelled between 2000 and 2015 from roughly US\$2 trillion to US\$12 trillion, generated an increased demand by central banks of emerging market and developing countries (EMDCs) for safe assets issued by Organisation for Economic Co-operation and Development (OECD) governments. Second, there is a growing demand for safe assets from private banks and financial institutions, which need such assets as collateral to fulfil their liquidity needs in wholesale funding markets, as well as to meet new post-crisis liquidity requirements. Finally, the supply of assets with high-quality ratings issued by private and public institutions in advanced market economies (AMEs) fell sharply in the wake of the global financial crisis (see Figure 1).

The latter development is especially important for understanding the persistent dominance of the US dollar. From the perspective of the global safe asset shortage, the international currency leader has to be a net provider of safe assets during times of stress. The crisis revealed that genuinely safe assets can only be produced by a state government that either issues sovereign debt securities or guarantees private assets (such as bank deposits). Indeed, 'a safe asset shortage is a deficit of a particular form of wealth (safe wealth), which the government has comparative advantage in supplying' (Caballero and Farhi, 2014). Although, before the crisis, the shadow banking system had been very inventive in creating highly rated private assets via the securitization of riskier assets and loans, the safety of these securitized assets proved to be elusive as their value crashed during the

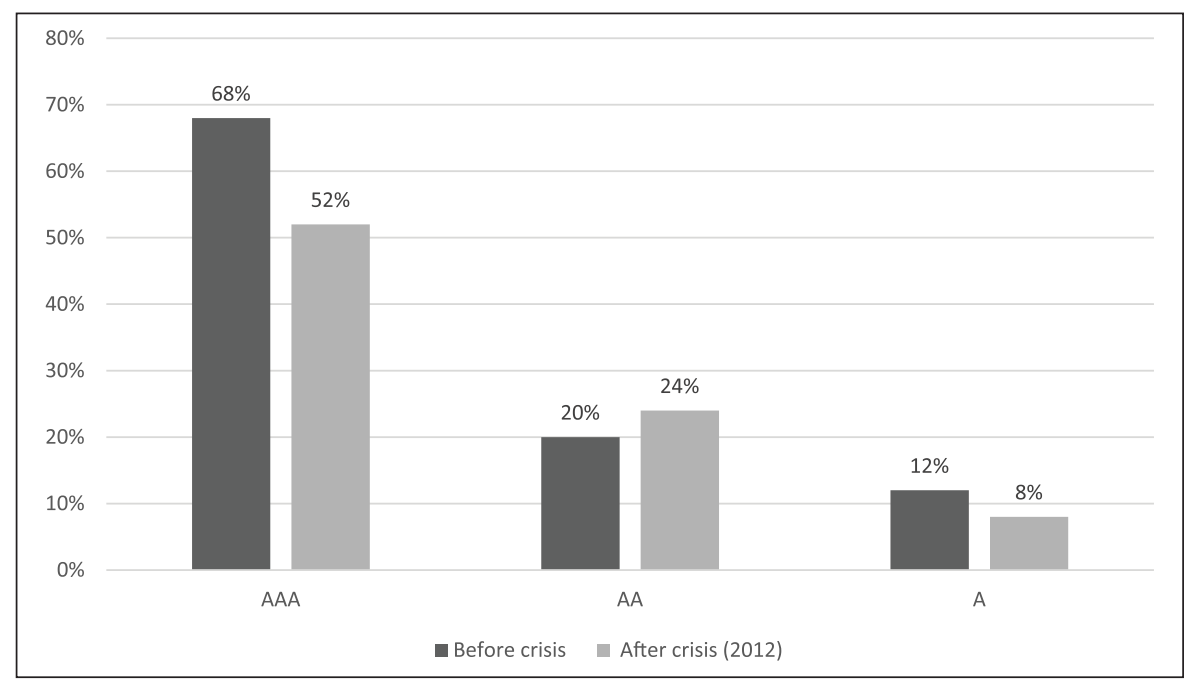

Figure I. Supply of highly rated assets by AMEs (in \% of total). Source: IMF (20I2). 
Table 2. Decline of safe assets from 2007 to $201 \mathrm{I}$.

\begin{tabular}{|c|c|c|c|c|}
\hline & \multicolumn{2}{|c|}{ USD billion } & \multicolumn{2}{|c|}{$\%$ of world GDP } \\
\hline & 2007 & 2011 & 2007 & 2011 \\
\hline US Federal government debt & 5,136 & 10,692 & $9.2 \%$ & $25.8 \%$ \\
\hline Held by the Federal Reserve & 736 & 1,700 & $1.3 \%$ & $2.5 \%$ \\
\hline Held by private investors & 4,401 & 8,992 & $7.9 \%$ & $13.3 \%$ \\
\hline GSE obligations & 2,910 & 2,023 & $5.2 \%$ & $3.0 \%$ \\
\hline Agency- and GSE-backed mortgage pools & 4,464 & 6,283 & $8.0 \%$ & $9.3 \%$ \\
\hline Private-issue asset-backed securities & 3,901 &,+ 277 & $7.0 \%$ & $1.9 \%$ \\
\hline German and French government debt & 2,492 & 3,270 & $4.5 \%$ & $4.8 \%$ \\
\hline Italian and Spanish government debt & 2,380 & 3,143 & $4.3 \%$ & $4.7 \%$ \\
\hline Safe assets & 20,548 & 12,262 & $36.9 \%$ & $18.1 \%$ \\
\hline
\end{tabular}

Note: Numbers are struck through when they lost their 'safe haven' status after 2007. GDP = gross domestic product; GSE = Government-sponsored enterprises.

Source: Barclays Equity Gilt Study 2012.

crisis (Gourinchas and Jeanne, 2012). However, the crisis also revealed that not all debt securities issued by sovereigns were seen as safe by international financial markets: when markets questioned the nominal debt-servicing capacity of peripheral Eurozone governments, their bonds were downgraded and lost their safety label. Due to downgrading in the some of the world's largest markets for private and public assets that were considered safe before the crisis, the global supply of safe assets more than halved between 2007 and 2012 (see Table 2). Therefore, the most important market to meet the world's demand for safe assets was still the market for US treasuries, which both relaxed the constraints imposed by the Triffin dilemma and consolidated the US dollar's international status.

These observations accord well with chartalist perspectives on money, pointing to the political foundations of international currencies as safe assets. As a state theory of money, chartalism easily accounts for the fact that only sovereign debt securities act as genuinely safe assets. According to this theory, the state's political authority is key to maintaining the liquidity and stability of the international monetary and financial system. First, the sovereign has the power to guarantee the 'legal tender status' of money, that is, it decides which medium of payment can be valid for meeting a financial obligation - especially tax obligations. Chartalists maintain that the origin of modern fiat money is not that it gave economic agents a commonly accepted medium of exchange to grease their trade in goods and services, but rather that it functioned as 'a means for accounting for and settling debts, the most important of which are tax debts' (Ingham, 2004: 47; see also Goodhart, 1998; Otero-Iglesias, 2015; Rochon and Vernengo, 2004; Wray, 1998): 'If the state is sovereign ... then it will be able to tax its citizens in the token it deems appropriate. The public at large uses the token of choice since it is useful for tax purposes' (Rochon and Vernengo, 2004: 59). This means that as long as the sovereign has both political legitimacy and 
economic capacity to tax its firms and citizens through its monopoly on violence, it cannot default on its liabilities. Even if private banks and financial institutions are able to create money endogenously, it also implies that the state should be the central guarantor of the system: 'It has a crucial role in infusing trust and stability to any monetary system because it is the main debtor (it issues debt to deliver public goods) and the main creditor (it has the capacity to tax, by force if need be)' (Otero-Iglesias, 2015: 6).

Second, the sovereign has the power to create high-powered money that has legaltender status. From a chartalist perspective, it is necessary to differentiate the state's 'outside money' from the 'inside money' created in the private banking and financial system (Tcherneva, 2005; Wray, 2014). As Schwartz (2017: x) notes, the creation of private credit is inherently unstable as private financial firms have an incentive to expand their balance sheets by creating excessive amounts of inside money:

In principle, this behavior nets out, but in practice an asymmetry plagues this accounting balance. While asset values can - and do - change in response to behavior by market actors, liabilities in the form of debt have values that remain stable in nominal terms until a formal bankruptcy.

As the state's outside money does not simultaneously generate an explicit financial liability, it is high-powered in the sense that it can be used to absorb the overhang of private liabilities revealed in a financial crash: due to the state's legitimate ability to coerce payments from the economy via taxation, 'the state's outside money is backed by the entire future stream of income generated inside the economy the state governs' (Schwartz, 2017: 8). Outside money usually refers to money created by the central bank, which can 'print' high-powered money to buy up devalued assets at par so as to re-establish balance in the financial system. The ultimate market backed by the central bank's power to create outside money is the market for public debt, which is an additional reason why it functions as a safe asset: 'In its own domestic currency the national state is essentially always creditworthy, and default is impossible, since the central bank can always buy government bonds and monetize the debt' (Fields and Vernengo, 2013: 746; see also Wray, 1998). ${ }^{1}$

By underscoring the necessity of a sovereign political authority to underpin any monetary space, chartalism argues that the diverging attractiveness of US treasuries and Eurozone sovereign bonds as global safe assets is linked to the lack of political integration in the European monetary union. There are three separate dimensions to this argument, the first two of which are also stressed by the broader literature on international currencies. A first dimension is that the Eurozone does not have a common defence policy and is therefore not able to project military power to the same extent as the US. As Norrlof (2014: 1047) argues, 'a strong military and naval power can be used to collect debt from faraway places and is an important political source of global currency status'. In the International Political Economy (IPE) literature, the claim that the global dominance of the US dollar is bolstered by the military preponderance of the US and the security umbrella that it provides to key dollar-supporting states (like Saudi Arabia, Japan and South Korea) is widely endorsed (e.g. Helleiner and Kirshner, 2009; Norrlof, 
2010; Otero-Iglesias, 2014; Stokes, 2014). ${ }^{2}$ The second dimension is the need for a fiscal union and an integrated market for sovereign debt. As sovereign bond markets remain segmented along national lines in the Eurozone, the creation of an integrated market for federal Eurobonds is generally seen as a precondition for the euro to rival the US dollar as an international currency (Eichengreen, 2011; Helleiner, 2008, 2015; McNamara, 2008; Otero-Iglesias, 2014). Many economists also believe that EMU should be combined with a certain degree of international fiscal transfers as a way to absorb the negative effects of asymmetric shocks.

The third dimension is that the monetary and fiscal policy nexus is more conducive to supporting the safety and liquidity of the public debt market in the US than in the Eurozone. Neo-chartalist economists wish to reassert the importance of fiscal policy over monetary policy by arguing that government deficits are appropriate and even necessary to provide the private sector with safe assets: 'The domestic private sector can only accumulate financial assets if the domestic public sector accepts to go into debt ... showing that public debt is not necessarily an evil' (Lavoie, 2011:4). ${ }^{3}$ However, the private sector will be only willing to hold government debt when there is no risk of government default. That is why the central bank needs to be able to lend money to the government by buying its debt securities: 'The central government of a "sovereign" nation, meaning here a nation where the central government can sell its securities to its central bank, can always finance its expenditures or roll over its debt by borrowing from its central bank' (Lavoie, 2011: 14-15). Since they allowed their sovereign to be denominated in euros rather than in their national currency, Eurozone governments 'surrendered not only their privileges of seignorage but also the ability to monetize their deficits' (Lucarelli, 2015: 23; see also Fields and Vernengo, 2013; Lavoie, 2015). This puts more pressure on them to pursue restrictive fiscal policies.

In the following, I argue that the absence of a supportive monetary and fiscal policy nexus has been the most critical constraint to the international role of the euro, although this dimension is mostly neglected in the IPE literature on international currencies. By emphasizing the importance of accommodating macroeconomic policies to inject safe asset liquidity in the world economy, a chartalist view on money even contradicts a prevailing hypothesis in this literature - that attaining and preserving international currency status requires the adoption of conservative monetary and fiscal policies to secure foreign confidence in the stability of the real value of the currency. In subsequent sections, I argue that the leading supplier of safe assets needs to pursue accommodating monetary and fiscal policies - especially during times of global shortages of safe assets. I explain why the EMU's relatively conservative macroeconomic policies constrain the ability of the region to be an equally large net seller of safe assets in the global economy as the US. More specifically, I show how the ECB's decisions on when to produce highpowered outside money liquidity and how to allocate that liquidity to private banks diverted the burden of macroeconomic adjustment onto trade deficit countries in the region.

The question is why the ECB took these decisions. A prevailing interpretation is that the ECB was legally bound by the TFEU to avoid direct fiscal transfers through its monetary policy and was hence unable to give equal treatment between core and 
peripheral sovereign debt. This would imply that the lack of fiscal union - and the absence of an available supranational safe asset in the form of a Eurobond, in particular - forced the ECB to be more cautious about peripheral sovereign debt: by being too lenient in its eligibility criteria and asset purchase decisions, its balance sheet would become overly exposed to peripheral sovereign debt and suffer substantial financial losses. Since these losses supposedly require a recapitalization of its capital through the injection of taxpayer money, excessive balance sheet exposure to vulnerable peripheral debt could lead to direct fiscal transfers between the Eurozone governments. In the following, I argue that the norm of central bank recapitalization does not have any legal foundation and appears to be based only on the alleged need to support the ECB's mandate to maintain low inflation in the region. As its restrictive decisions took place in a deflationary context - and even contributed to that context - a more valid interpretation is that there has been a deflationary bias in the ECB's handling of the financial and euro crisis. To the extent that the ECB's deflationary bias can be linked to the absence of political union, this is only due to its reluctance to pursue monetary policies that would be considered as illegitimate by the majority of the citizens and politicians from the northern countries by potentially clashing with their desire to preserve low inflation and low public debt levels in the region. In this regard, the absence of political union might have constrained the establishment of a more supportive macroeconomic policy nexus in the Eurozone - not because of the lack of a fiscal union, but because of the conflicting macroeconomic policy preferences between northern and southern countries as, respectively, 'creditor' and 'debtor' countries and the absence of a neutral political mediator between these interests. Before making these arguments, I review the literature on the relationship between international currency leadership and macroeconomic policy and discuss several theoretical reasons why conservative institutions can be harmful for such leadership.

\section{Macroeconomic policy, international currencies and safe assets}

A prevailing understanding in the literature on international currencies is that international currency status hinges upon a relatively orthodox macroeconomic policy framework: rules targeting low inflation and balanced budgets are necessary to maintain foreign confidence in the stable real value of the currency by constraining the capacity of its issuer to pursue inflationary policies. As Walter (2006: 51) argues: 'currency leadership requires a relatively conservative monetary policy from the leader that is credibly embedded in its domestic political and economic institutions'. This prerequisite is believed to be particularly important in the modern era of fiat money, which inherently creates the potential for inflation and requires a commitment to a low-inflation monetary policy that is made credible by guaranteeing the political independence of the central bank. Moreover, the currency issuer needs to refrain from pursuing inflationary fiscal policies and be committed to balanced budgets and low public debt levels: 'very large fiscal deficits in the center country, by raising real interest rates in the entire system, erode the legitimacy of the 
monetary leader vis-à-vis other countries' (Walter, 2006: 66). A number of prominent scholars of international currencies have argued that the US exploited the 'exorbitant privilege' associated with issuing the world's key currency by pursuing irresponsible macroeconomic policies, which led to 'very large and sustained US federal budget deficits' that 'warn of the threat of future inflation' (Kirshner, 2008: 419; see also Calleo, 2009; Eichengreen, 2011; Layne, 2012; Otero-Iglesias and Steinberg, 2013). ${ }^{4}$ In terms of monetary policy, a common interpretation is that 'the Fed's quantitative easing (QE) policies have undermined its reputation as a hawkish central bank' (Otero-Iglesias and Zhang, 2013).

If rising public indebtedness and QE policies are detrimental to the dollar's long-term stability, why is the market for US treasuries still seen by foreign investors as the world's ultimate market for safe assets? One possible explanation is that domestic owners of US public debt have sufficient influence over the US government to keep it from pursuing inflationary policies, strengthening foreign confidence in the safe asset status of US treasuries. Drawing on his research on the highly unequal ownership structure of US public debt, Hager argues that the top 1\% of the most affluent US households - who own $33 \%$ of total US public debt (averaging US\$1.15 million per capita) directly or indirectly through mutual and pension funds - has a key stake in the creditworthiness of US treasuries:

[These] owners of the US public debt would bear a significant cost if the US were to inflate away its debt burden.... Foreigners, even if they are not explicitly aware of it, can maintain confidence in US Treasuries thanks in large part to the power of domestic owners, who play a key role in pressuring the federal government to uphold its debt obligations. (Hager, forthcoming: 8)

As such, the impression here also is that the safe asset status of US treasuries can only be ensured if "governments commit themselves to the principles of "sound finance" which is safeguarded by the structural power of the domestic owners of US public debt (Hager, forthcoming: 14).

Another explanation of the persistent dominance of the market for US treasuries is the lack of an alternative equally large, deep and liquid market for safe assets. The Chinese market for government bonds is fragmented along different instruments and trading platforms and restricted for foreign investors through capital controls (Ma and Yao, 2016). As discussed earlier, fragmentation is even more problematic in the Eurozone, where the vast aggregate sovereign bond market is only a compilation of national public debt markets. Yet, at the same time, the presence of conservative macroeconomic policy institutions was usually seen in the pre-crisis literature as one of the most attractive features of the euro as an international currency. As Helleiner (2008: 360-361) summarized this perspective:

foreign confidence in the euro is certainly boosted by the fact that it has been embedded by its creators in a very conservative institutional context. Not only has the ECB been explicitly mandated (unlike the US central bank) to pursue low inflation, but its ability to fulfill this mandate has been strengthened by its legal independence (again, different from the Fed) from the influence of governments. (See also Chey, 2012; Otero-Iglesias, 2014) 
The restrictive fiscal stipulations of the Stability and Growth Pact (SGP) and rules prohibiting the monetary financing of government deficits were also supposed to contribute to price stability by bolstering the political independence of the ECB. According to one former member of the ECB's Executive Board:

the institutional setting of the ECB, with its independence from political pressure and its mandate to preserve price stability, helped to rein in inflationary pressures and indirectly fostered the confidence of domestic and foreign residents in the capacity of the euro to preserve its value. (Bini Smaghi, 2009: 28)

There are several good reasons to challenge the view that anti-inflationary macroeconomic policies are conducive to the ability of a state or region to be an important producer and international supplier of safe assets. First, it can be argued that avoiding the potential of outright default is more important than minimizing the potential of partial default via inflation: the absence of default risk and the promise of nominal debt repayment are more critical in the definition of a safe asset than maintaining the stability of its real value. In this regard, both chartalist scholars and economic researchers of the global safe asset shortage have pointed to the vital role of monetary policy in preserving the safety of domestic-currency debt. As Gourinchas and Jeanne (2012: 24) note:

a central bank can make any domestic-currency debt asset safe by providing it with a 'monetary backstop', i.e., by committing to provide the issuer with the currency required to repay the debt or to buy the asset itself at the no-default price.

This is particularly important in the market for public debt assets, which play a fundamental role in meeting the liquidity needs of private banks and maintaining the stability of the general financial system. For this reason, government default needs to be avoided at all costs: the central bank must be a lender of last resort to the government (LLR), which is then able to guarantee the nominal repayment of its debt whenever it fails to collect sufficient tax income and risks losing access to financial markets (Fields and Vernengo, 2013; Lavoie, 2015; Lucarelli, 2015). Apart from actual or potential asset purchases, the central bank's collateral rules affect 'banks' ability to preserve access to (repo) market funding in crisis' (Gabor and Ban, 2016: 5; Orphanides, 2017). This underscores the need for flexible and lenient collateral rules and policies during times of crisis.

Second, overly restrictive fiscal policies can have negative effects on the stability and liquidity of the international financial system by reducing the supply of sovereign debt securities to domestic and foreign investors. As noted earlier, chartalist economists argue that fiscal deficits are necessary to inject safe assets into the financial system (Lavoie, 2011; Wray, 1998). This is especially important during safe asset shortages (Caballero and Farhi, 2014). As private banks have extra need for high-quality and liquid assets ensuing from new prudential regulation (e.g. the Liquidity Coverage Ratio of the Basel III agreement), 'the private sector will be a negative supplier of safe assets', so 'for the foreseeable future, only public debt will provide additional supply of safe assets' (Landau, 2013: 251). Holders of foreign exchange reserves will be 'competing' with the private sector to get a hold of AAA/AA/A sovereign debt securities, so their desire for safe assets 
can only be satiated by highly rated governments willing to accumulate fiscal deficits and sell sovereign bonds. Some economists hence identified a new 'fiscal' version of the Triffin dilemma as these deficits could, in the longer term, undermine market confidence in the sustainability of the public debt (Farhi et al., 2011; Obstfeld, 2013). From a chartalist perspective, however, a monetary sovereign who issues debt in a currency that it fully controls faces less revenue constraints on fiscal deficits than mainstream economists assume: the government can always service its debt through central bank credits to accounts of bondholders and the central bank can also avoid an unsustainable debt explosion due to rising interest rates, which are ultimately under its control (Wray, 2014).

There is also a practical reason why conservative macroeconomic policies can be less favourable to international currency status than accommodating policies: by repressing domestic demand, restrictive monetary and fiscal policies will usually lead to a surplus of the trade balance, constraining the ability of an international currency issuer to meet foreign demand for safe assets. There is an ongoing and unsettled discussion in the literature as to whether the issuer of the international currency needs to run deficits on either the capital/financial or current account of the balance of payments to inject liquidity into the world economy. Both Britain and the US ran capital/financial account deficits during the first stages of the internationalization of the British pound and the US dollar. Nevertheless, as Germain and Schwartz (2014: 1100) argue, capital/financial deficits have global deflationary consequences that will eventually induce the currency issuer to run current (trade) account deficits:

The international currency emitter cannot validate its long-term external assets unless that country runs trade deficits, allowing the periphery to service its long-term external debts to the emitting country. When Britain and the United States engaged in this form of global intermediation or arbitrage they ineluctably ended up running trade deficits to validate their foreign investments.

From the perspective of the safe asset shortage, there is another (neglected) reason why the international currency issuer has to run trade deficits: these deficits are the only feasible way to become a large net international seller of safe assets, which requires large surpluses on its debt securities account (one of the components of its financial account). As an accounting identity, large surpluses on the debt securities account can only combine with surpluses on the current account if there are even larger deficits on the other key components of the capital/financial account (the foreign direct investment and equity investment balance). This means that the international currency issuer would accumulate a vast net stock of foreign direct investments and foreign equities. To put it in perspective, Figure 2 shows that the key parallel components of the US balance of payments are the trade and debt securities balance: if the US had not run an average annual deficit of US $\$ 495$ billion between 1999 and 2016, it would have had to acquire, on average, almost 10 times as much foreign direct investment and equity assets on a net term basis than it did during this period. This would have led to a (geo)politically unacceptable high level of US penetration of foreign economies and businesses.

These three reasons do not necessarily imply that the monetary and fiscal policy nexus of the US has been optimal to its role as the world's dominant net international 


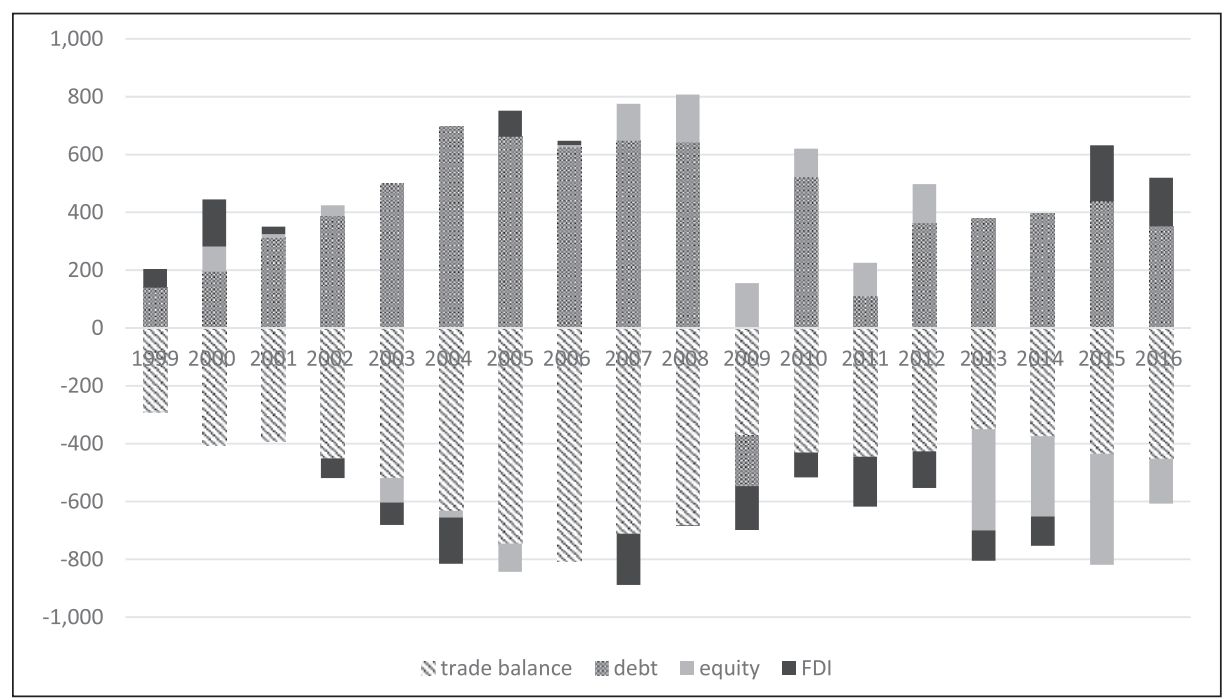

Figure 2. Main components of the US balance of payments, in billions of US dollars. Note: $\mathrm{FDI}=$ foreign direct investment.

Source: BEA.

supplier of safe assets. However, they do suggest that its relatively accommodative macroeconomic policy institutions and policies have been more helpful to that role than the relatively conservative monetary and policy institutions and policies in the Eurozone, which have even intensified the global safe asset shortage since the crisis. Why has this been the case? In the next two sections, I draw attention to the role of the ECB, whose discretionary decisions on when and how to create and allocate outside money to European banks and governments contributed to a deflationary macroeconomic policy regime that led to a rising aggregate trade surplus for the region.

\section{Macroeconomic policy and safe assets in the Eurozone}

From a chartalist perspective, the introduction of the euro weakened 'the centrality of the link between political sovereignty and fiscal authority on the one hand and money creation, the mint and the central bank, on the other ... to a degree rarely, if ever, known before' (Goodhart, 1998: 409). In the absence of a political union, a restrictive and orthodox macroeconomic policy framework was established 'to convince market operators that [the euro] was a strong currency with a fiercely independent European Central Bank which would never allow the monetization of debt' (Otero-Iglesias, 2017: 4). That framework has been based on principles of 'monetary dominance': national fiscal policy has to play a passive role in the economy and be subordinated to the ECB's monetary policy, which needs to retain control over interest rates to preserve price stability. Euro architects believed that it was necessary to avoid 'fiscal dominance', a situation in which the monetary authority is forced to accommodate fiscal spending through inflation and/or 
monetary financing in order to keep the government solvent: heavily indebted governments risk forcing the central bank to accept higher inflation to lower the real value of their debt. To prevent this danger, Eurozone governments agreed to subject their fiscal policy to restrictive rules that served to diminish inflationary pressures and support the price stability mandate of the ECB.

\section{The $E C B$ and the perseverance of monetary dominance}

A major inconsistency of the regime of monetary dominance was 'the combination of the no-bail-out and the no-debt-monetization clauses with a lack of institutional mechanisms to deal with an actual sovereign default' in the Eurozone (Braun, 2015: 434). These clauses prevented peripheral Eurozone governments from guaranteeing that they would have the necessary liquidity to pay out their outstanding sovereign bond at maturity. As a representative of the ECB recognized during the first stages of the crisis:

the euro area is ... the only area of the world where monetary and fiscal institutions are completely separate, in which the fiscal authority cannot count on the monetary authority, not only to prevent a solvency problem, but also a liquidity problem. (Bini Smaghi, 2009: 3)

In the US, as discussed earlier, there is an implicit guarantee that the Federal Reserve is the LLR in the market for US treasuries, which assures foreign holders of these treasuries that the US government will always have sufficient liquidity to roll over its liabilities and remain solvent in the face of rising fiscal deficits and public debt levels. As De Grauwe (2013: 521) has argued: '[t]he absence of such a guarantee makes the sovereign bond markets in a monetary union prone to liquidity crises and forces of contagion, very much like banking systems that lack a lender of last resort'. The lack of a monetary backstop pushed peripheral governments into a 'bad equilibrium' by creating self-fulfilling expectations of insolvency among international investors: they feared that these governments would not have adequate liquidity to meet their domestic and foreign liabilities and started to withdraw their money, leading to punitive sovereign debt yields (see also Lavoie, 2015).

Several scholars have argued that the ECB's reluctance to act as an LLR in sovereign bond markets was key in imposing austerity policies and structural reforms on governments in the region and pushing them to establish more stringent fiscal policy rules (Henning, 2015; Woodruff, 2016). During the first stages of the euro crisis when the Greek crisis escalated in the spring of 2010, the ECB launched its Securities Market Programme (SMP) only after the Eurozone government and state leaders agreed to establish a permanent European Financial Stability Facility (EFSF) to provide official loans to distressed governments conditional on the adoption of harsh fiscal consolidation measures and labour market reforms. The SMP was limited in scope and timing, however: its purchases of bonds issued by the five peripheral countries were limited to $€ 218$ billion and proved incapable of stabilizing sovereign bond markets - especially those of Spain and Italy. Continuing stress in these markets led the ECB to launch long-term refinancing operations (LTROs): in exchange for European leaders' commitment to strengthen EMU's macroeconomic governance framework (via the 'six pack' in the autumn of 2011, 
which included the highly asymmetrical macroeconomic imbalances procedure and the introduction of the Fiscal Compact in December 2011), it injected $€ 1,020$ billion into the financial system by offering Eurozone banks three-year loans at very low interest rates (1\%) in two rounds of LTROs (one in December 2011 and the other in February 2012).

Two problems prevented the ECB from stabilizing Spanish and Italian sovereign bond markets via its LTRO programmes. First, by encouraging peripheral banks to engage in carry trades, the LTROs increased the 'home bias' in their sovereign debt holdings: they could borrow from the ECB at 1\% and invest the capital into higheryielding debt securities issued by their governments (Acharya and Steffen, 2013). While this might have been an implicit intention of the ECB, it also intensified the "vicious cycle' between banking instability and the sovereign debt crisis: peripheral banks deepened their exposure to sovereign default and weakened their balance sheets, increasing the threat that their government would need to raise additional debt to bail out its banks. Second, its balance sheet became exposed to losses as banks could default or the value of their pledged collateral could fall in the face of continuing market distress. While initially relaxing collateral standards and eligibility criteria to allow banks from peripheral member states to make maximum use of its LTRO funds, the ECB ultimately decided to adopt risk practices of repo market participants. To avoid that its liquidity operations would be subjected to political contestation by northern Eurozone governments, it started marking its collateralized assets to market, applying haircuts and making margin calls when these assets fell in market value (Gabor and Ban, 2016). By making margin calls and raising haircuts on collateralized sovereign debt issued by peripheral governments, the ECB made it less easy and attractive for banks and nonfinancial institutions to use these assets as collateral in private repo agreements. As such, its pro-cyclical collateral policies undermined the external funding needs of peripheral banks that held these assets on their balance sheets.

The ECB could only solve these problems by assuming a more direct LLR role in sovereign bond markets. On 26 July 2012, Mario Draghi pledged 'to do whatever it takes to save the euro', leading to a commitment made on 6 September 2012 to engage in 'outright monetary transactions' (OMTs): the ECB promised to buy an unlimited amount of distressed-country sovereign bonds in secondary markets once a government had formally applied for a bailout programme at the European Stability Mechanism (ESM). The OMT announcement was especially important in reinstating the perceived safety of Spanish and Italian public debt, which accounted for about one-third of the Eurozone's aggregate public debt in 2012 (see Figure 3). The announcement was very effective in mitigating the default risk premium and interest rates on peripheral sovereign debt by giving investors an implicit promise that the ECB would intervene when push comes to shove. At the same time, the programme came with various conditions, suggesting that the ECB was not entirely willing to act as a genuine LLR in public debt markets. OMTs would only consist of sterilized purchases of sovereign bonds with a short maturity of one to three years, leaving the market for longer-term sovereign bonds without a monetary backstop. Furthermore, to avoid moral hazard, a crucial condition for the OMT is that the profiting government abides by the 'strict and effective conditionality' attached to an 'appropriate' ESM programme. Yet, as De Grauwe (2013: 527-528) notes: 


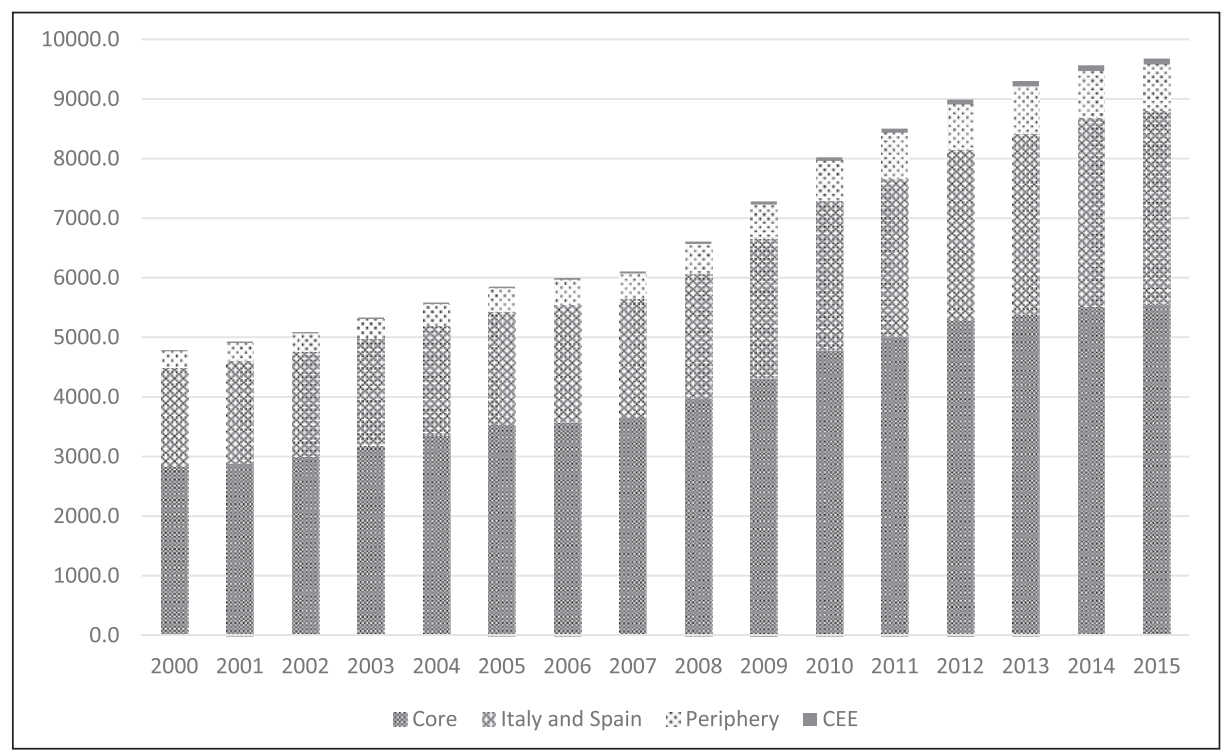

Figure 3. Government consolidated gross debt in billions of euros.

Note: $\mathrm{CEE}=$ Central and Eastern European member states.

Source: OECD.

the central bank must be willing to provide unlimited support without making this support conditional on good behavior. If the [ECB] tries to solve a moral hazard problem, it will fail in its duty to be a lender of last resort.

The conditionalities attached to OMT again reflect the ECB's aspiration to make sure that its intervention in sovereign bond markets would not let Eurozone governments escape the path of fiscal discipline. By doing so, the ECB played a key role in constraining the Eurozone's ability to be a net international seller of safe assets in the world economy. As Figure 4 shows, those countries experiencing a sharp decline in the domestic money supply (measured by annual M3 growth) due to rising sovereign debt yields were also the ones who adopted the harshest austerity policies (measured by the consolidation of the primary government budget). However, the same figure shows that expansionary monetary conditions in the core Eurozone countries have not provoked fiscal policy expansion by governments in these countries, which have also consolidated their primary budget even in the face of sharp M3 growth. While the European Union (EU) treaties - and the newly established Fiscal Compact - compelled northern governments to cut their public deficits, restrictive fiscal policies also bolstered the competitiveness of their export-oriented firms by sharpening the incentives for wage restraint among trade unions (Carlin and Soskice, 2009; Iversen and Soskice, 2013). As a result of these austerity policies, the Eurozone's creation of additional public safe assets has stagnated as a percentage of world gross domestic product (GDP) since the start of the global financial and euro crisis (see Figure 5). From the perspective of the global safe asset 


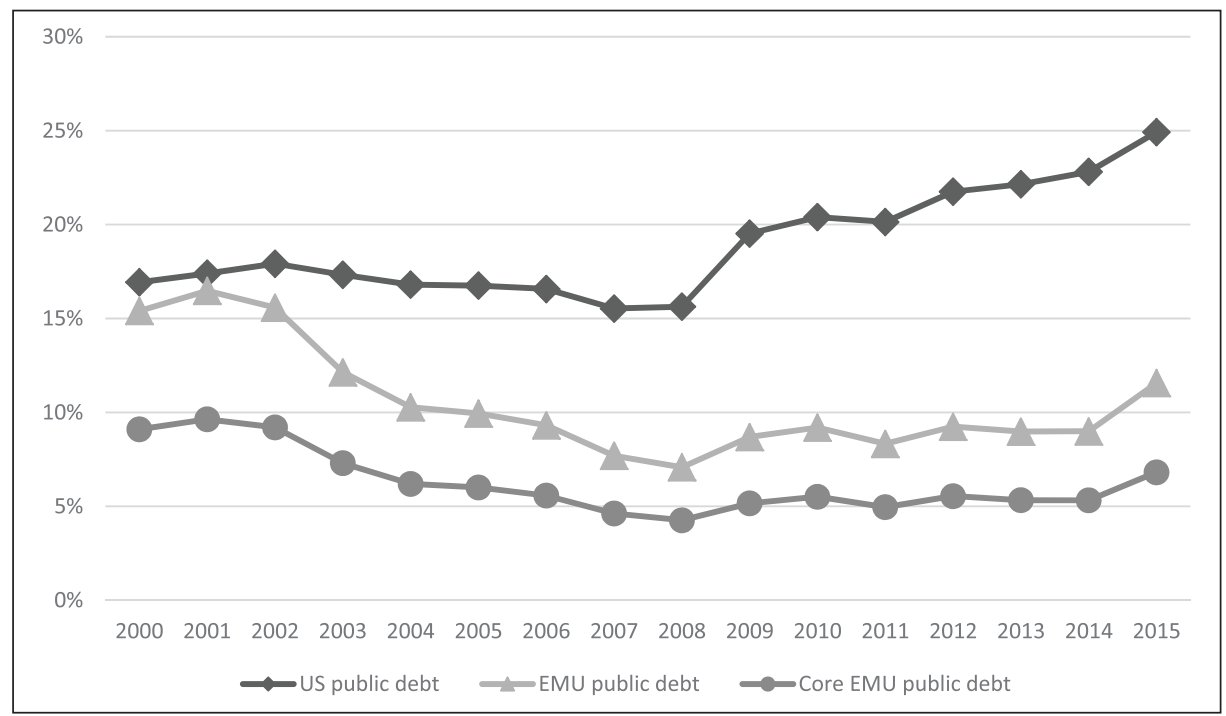

Figure 4. Public debt as a percentage of world GDP.

Source: US Bureau of Economic Analysis, Eurostat and IMF World Economic Outlook Database.

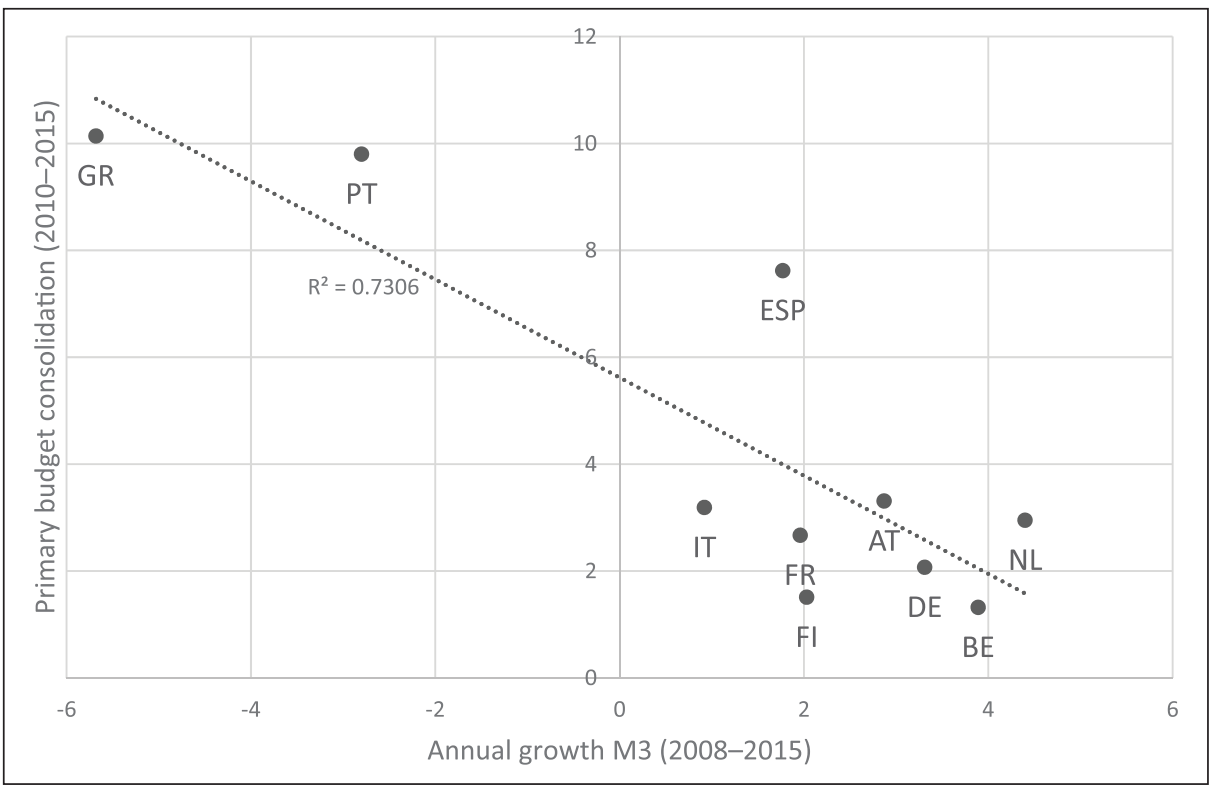

Figure 5. Primary budget consolidation and annual growth M3.

Source: Eurostat, national central banks and author's calculations.

shortage, this stagnation was especially problematic for the core Eurozone countries, who continued to issue highly rated sovereign debt. By contrast, fiscal deficits in the US 


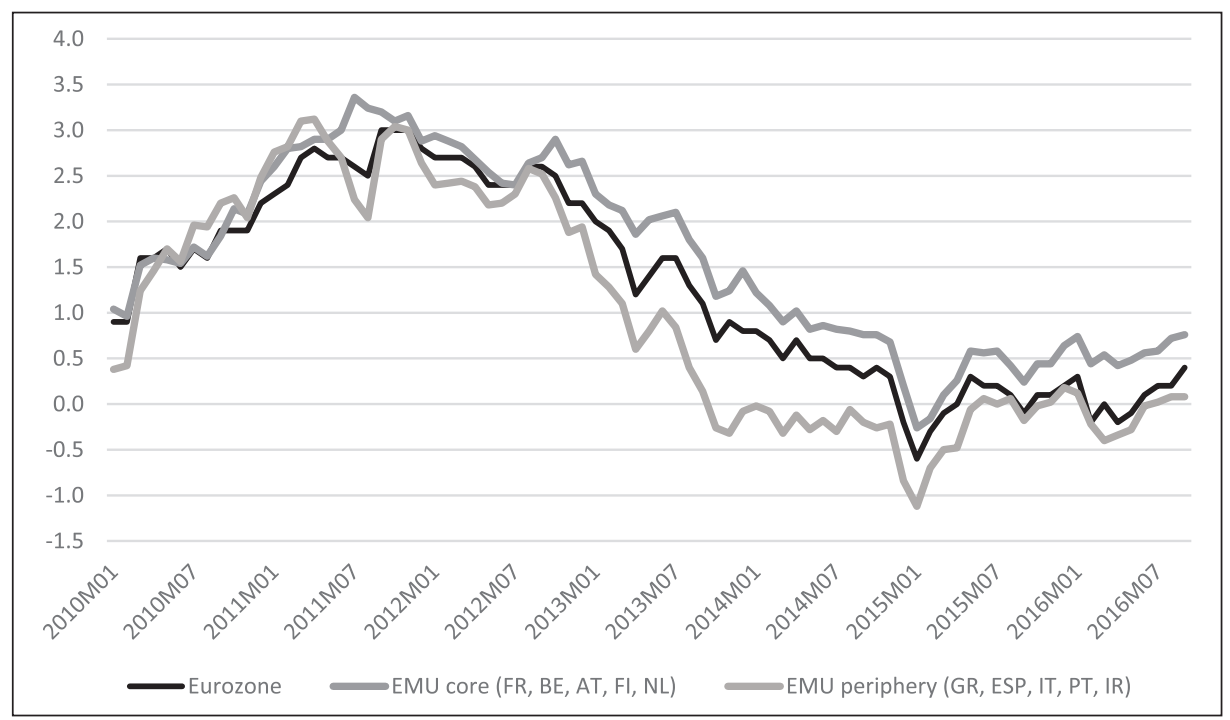

Figure 6. Inflation rates in Eurozone, core and peripheral countries.

Source: AMECO and author's calculations.

enabled a sharp rise in the generation of safe US public debt assets as a percentage of world GDP.

Austerity not only constrained the ability of the Eurozone to produce safe assets; it also undermined the region's potential to provide these assets on a net term basis to the rest of the world. It is well known that austerity policies are part and parcel of the internal devaluation strategies that have been imposed on the region's debtor economies in order to improve their competitiveness. Apart from fiscal consolidation, internal devaluation is based upon a deregulation and decentralization of the labour market in order to reduce unit labour costs (ULCs), which is deemed necessary to regain competiveness vis-a-vis the northern creditor countries and improve their current account balance: these measures depress domestic demand and reduce wage growth and ULCs by fuelling unemployment (especially in non-traded sectors). Austerity policies contributed to deflationary conditions in the Eurozone by depressing economic growth: inflation rates declined in both the core and peripheral countries, yet much harsher fiscal consolidation made the decline much larger in the latter countries (see Figure 6).

By January 2015, the fall in regional inflation prompted the ECB to finally initiate a QE programme consisting of monthly purchases of public and private sector securities amounting to $€ 60$ billion (afterwards raised to $€ 80$ billion) and to be carried out until September 2016 (later extended to March 2017). As all the Eurozone's national sovereign debt market (except Greece's) are included in its QE programme and its purchases are done according tothe ECB's capital key without any attached policy conditions, it might seem that the ECB has ultimately become a genuine LLR to Eurozone governments. However, it was decided that the ECB cannot buy more than $33 \%$ of the sovereign bonds of a single issuer and $25 \%$ of a single issue. Furthermore, $80 \%$ of the 


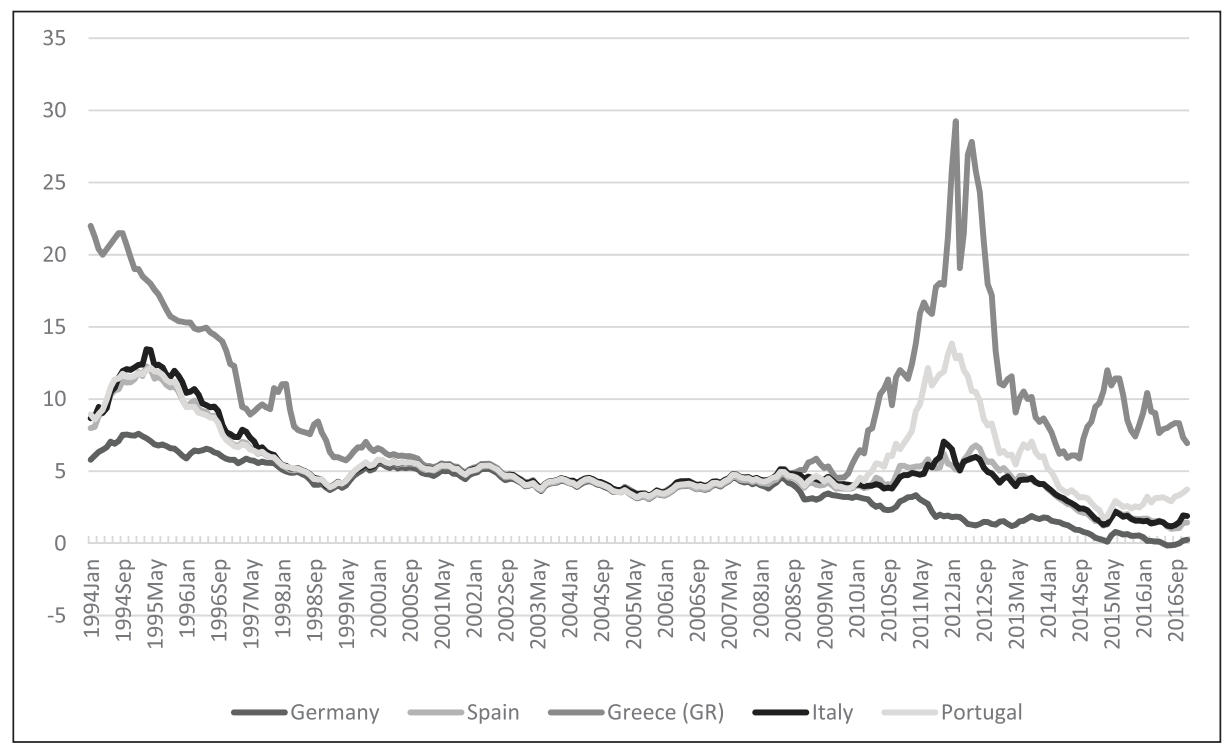

Figure 7. Interest rates on 10-year sovereign bonds of selected Eurozone countries. Source: ECB.

asset purchases had to remain on the balance sheets of national central banks (NCBs), potentially re-establishing a vicious cycle between sovereign default and bank instability at the level of the NCB: 'If the government were to default, this may make the national central bank insolvent and depositors less certain about repayment, possibly leading to capital flight' (Armstrong et al., 2015). More importantly, as Orphanides (2016) observes, by delegating the purchases of sovereign bonds to NCBs, 'the ECB signaled that it wished to account for the possibility of states leaving the euro area and protect its balance sheet against such eventualities': the ECB would be fully protected from the possible loss in case a country exits the euro and devalues its currency. As such, it opted to reinforce spreads between peripheral sovereign bonds and those issued by the northern countries, especially Germany's: 'Effectively the ECB used its discretionary power to introduce an implicit tax on member states perceived as weak and a subsidy on member states perceived as strong' (Orphanides, 2016: 15) (see Figure 7). Indeed, as Figure 7 shows, the yield spread between the 10-year sovereign bonds of the peripheral countries and German bunds even increased between January 2015 (when the ECB started with its QE programme) and January 2017.5

Hence, the ECB's discretionary decisions as to when and how to create and allocate outside money to Eurozone governments and banks caused an asymmetric distribution of macroeconomic adjustment costs between peripheral countries and northern countries. As Figure 8 shows, this led to a high surplus on the Eurozone's aggregate current account balance (which mostly consists of its trade balance). While rising surpluses of the exportled northern countries and deficits of the debt-led peripheral countries created a regional current account that was approximately in balance from 2000 to 2008, internal 


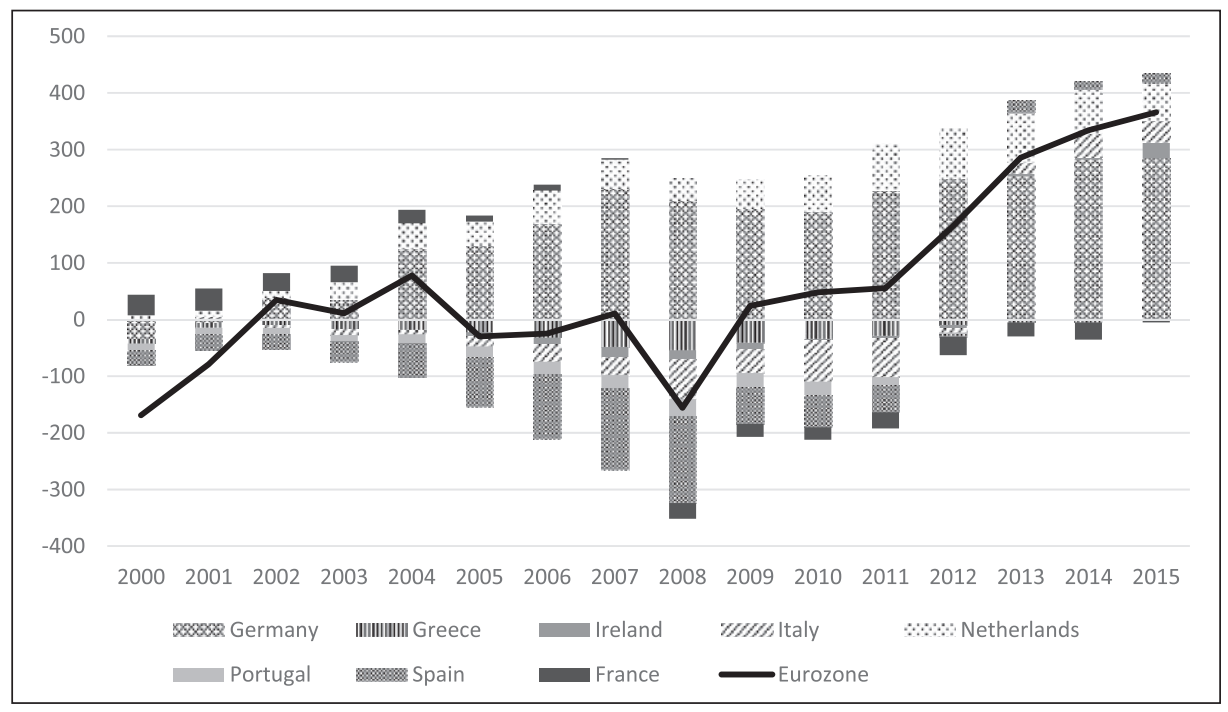

Figure 8. Current account balance of selected EMU countries, in billions of US\$. Source: IMF World Economic Outlook.

devaluation strategies evaporated the latter countries' external imbalances from 2010 to 2015. At the same time, northern countries maintained and, in some cases, even increased their external surpluses. From a varieties of capitalism perspective, the lack of adjustment is remarkable in light of the loose domestic monetary conditions ensuing from these policies as trade unions in these coordinated market economies could be expected to 'no longer be bound to their commitment to coordinate wage restraint' and push for inflationary wage agreements that would undermine the competitiveness of their exportoriented sectors (Iversen and Soskice, 2013; Soskice, 2007). ULCs and national inflation failed to increase stronger in these countries because their governments also pursued fiscal consolidation after 2010: export-oriented sectors do not have to fear the inflationary effects of the ECB's expansionary monetary policy on trade unions' wage demands as long as their governments are wedded to preserving their competiveness by pursuing a non-accommodating fiscal policy. Although ULC-based internal reflation did not really take place in the northern Eurozone countries, the ECB's monetary policy contributed to the euro's depreciation and enabled their firms to shift export markets to the rest of the world (Vermeiren, 2017). ${ }^{6}$

These dynamics intensified the global safe asset shortage: as discussed earlier, foreign demand for liquidity should be met by being a net seller of key currency-denominated safe assets to the rest of the world, implying that the issuer of the international currency needs to run a surplus on its debt securities account. Table 3 shows that the Eurozone's debt securities balance moved from a surplus to an enormous deficit from 2008 to 2015, paralleling the transition of its aggregate current account balance towards a huge surplus; in other words, it became a net purchaser of debt securities from the rest of world. This stands in stark contrast to the US, which still has a massive surplus on its debt securities 
Table 3. Balance of payments and key components, in billions of US\$.

\begin{tabular}{lrrrrrrrr}
\hline & 2008 & 2009 & 2010 & 2011 & 2012 & 2013 & 2014 & 2015 \\
\hline US & & & & & & & & \\
Current account & -691 & -384 & -442 & -460 & -447 & -366 & -392 & -463 \\
Financial account & 731 & 231 & 437 & 516 & 441 & 391 & 287 & 195 \\
$\quad$ Direct investment & -19 & -160 & -95 & -183 & -135 & -118 & -136 & 31 \\
$\quad$ Portfolio investment & 808 & -19 & 621 & 226 & 498 & 31 & 119 & 97 \\
$\quad$ Debt securities & 643 & -174 & 521 & 110 & 363 & 381 & 396 & 478 \\
$\quad$ Other investment & -21 & 417 & -101 & 453 & 89 & 477 & 246 & 36 \\
Eurozone & & & & & & & & \\
Current account & -172 & 19 & 31 & 32 & 162 & 287 & 320 & 359 \\
Financial account & 467 & -28 & 70 & 153 & -150 & -465 & -491 & -305 \\
$\quad$ Direct investment & -334 & -66 & -83 & -139 & -14 & 78 & -79 & -121 \\
$\quad$ Portfolio investment & 354 & 349 & 110 & 454 & 181 & 5 & -150 & -223 \\
$\quad$ Debt securities & 362 & 294 & -9 & 202 & 45 & -12 & -279 & -394 \\
$\quad$ Other investment & 418 & -239 & 53 & -142 & -256 & -522 & -199 & 146 \\
\hline
\end{tabular}

Source: US Bureau of Economic Analysis, ECB and OECD.

balance. This is linked to the US current account deficit, which remains sizeable and implies that the US continues to accumulate net foreign liabilities to finance these deficits. As such, the US remains the largest net seller of safe assets in the world economy, bolstering the international status of the US dollar.

\section{Was the ECB bound by the lack of fiscal union?}

A possible interpretation of the ECB's reluctance to act as LLR to Eurozone governments is that it was bound by the incompleteness of the EMU and the lack of fiscal union. Henning (2015: 1) notes that the ECB confronted a complex set of political and institutional challenges: 'Its currency area was fragmented politically like no other, among 19 member states that retained ultimate fiscal sovereignty notwithstanding common rules'. This is also how the ECB legitimized its decisions. Benoit Coeuré (a member of the ECB's Executive Board) explained in quasi-chartalist language that the key reason why US public debt is risk-free in nominal terms is that there can be full consolidation between the balance sheet of the Federal Reserve and the US Treasury. In the Eurozone, by contrast, 'government bonds are equivalent, in some ways, to "sub-sovereign" issues, since the [19] different fiscal authorities and the central bank cannot be consolidated within a single "federal" balance sheet' (Coeuré, 2016). Therefore, a critical difference between US treasuries and bonds issued by Eurozone governments is that the latter 'have to be made safe through sound fiscal policies, rather than assumed to be safe': the risk of default and government bond yields are assumed to be 'partly responsive to the outcome of fiscal policies' (Coeuré, 2016: original emphasis). In recent research by the ECB, it is argued that the lack of an integrated market for sovereign bonds constrained the Eurozone's monetary and fiscal policy nexus in ways that made the Eurozone prone to undesirable macroeconomic 
policy outcomes (Jarocinski and Mackowiak, 2017). So, according to the ECB's official interpretation, the lack of fiscal union prevents it from guaranteeing the safety of bonds issued by Eurozone governments: TFEU rules were designed to avoid fiscal dominance over monetary policy by ensuring that 'fiscal transfers do not take place through the central bank' (Coeuré, 2016).

This begs the question: do sovereign bond purchases by the ECB inevitably lead to fiscal transfers between Eurozone governments? Three concerns about the fiscal implications of its liquidity facilities and asset purchases could have urged the ECB to answer this question affirmatively. First, peripheral governments obtain fiscal benefits if the ECB purchases their public debt to stabilize their sovereign bond markets: these purchases will normally reduce the yields on these bonds, enabling governments to fund themselves at lower interest rates. This is particularly problematic if its asset purchase programme only contains peripheral sovereign bonds, as was the case in the SMP. Second, the ECB can earn net profits from its asset purchase programmes, a large share of which is redistributed to the NCBs according to their share in the ECB's capital key. Finally, and most problematically, asset purchases expose the ECB to default risks and valuation losses; these net profits can turn into net losses. The ECB's equity position can turn negative and necessitate recapitalization by national governments according to the share of NCBs in its capital key: in 2010, for instance, the ECB's Governing Council decided that a recapitalization of $€ 5$ billion was required to support its balance sheet in the face of potential losses associate with its SMP. Thus, sovereign bond purchases could provoke transfers of taxpayer money from fiscally strong governments (especially from large countries like Germany, whose share in the capital key is around 18\%) to fiscally weak governments (for an overview and discussion of these concerns, see Högenauer and Howarth, 2016).

Nevertheless, there are important counterarguments to each of these concerns. First, the concern that the fiscal gains from intervening in peripheral bond markets exclusively go to peripheral governments overlooks the fact that the lack of a backstop for these markets provided fiscal benefits to the core countries during the crisis:

By injecting risk in euro-denominated debt issued by the governments of member states perceived to be relatively weak (debt that was considered safe before the crisis), the global demand for euro-denominated safe assets was diverted away from these states towards the debt of the states perceived to be relatively strong. (Orphanides, 2017: 8; see also De Grauwe, 2013)

Second, as De Grauwe and Ji (2015) have convincingly argued, the ECB could structure its asset purchase programmes in ways that avoid fiscal transfers. By applying rules like 'juste retour' (whereby the ECB would redistribute the exact amounts of interest payments it received from each government back to the same government), 'the need to create additional money base to achieve the inflation target of $2 \%$ makes it possible to write down a significant part of the government debt on the ECB's balance sheet without creating fiscal transfers between member states' (De Grauwe and Ji, 2015; see also Paris and Wyplosz, 2014). In contrast, under the present rule (whereby the ECB pools the revenues and then distributes them to the NCBs according to their share in the capital key), there 
are even minor fiscal transfers from peripheral governments to core governments as interest rates on peripheral sovereign bonds are higher than those on core bonds. Third, there are conceptual and empirical reasons to question the notion that the ECB has to recapitalize its balance sheet to avoid the situation where its equity position turns negative.

While there are no legal recapitalization requirements in the TFEU, the informal view at the ECB is that 'any situation should be avoided whereby for a prolonged period of time an NCB's net equity is below the level of its statutory capital or is even negative'; when that situation does occur, 'the respective Member State provides the NCB with an appropriate amount of capital at least up to the level of the statutory capital within a reasonable period of time so as to comply with the principle of financial independence' (ECB, 2010: 21-22). Yet, there is no consensus among economists about the risks of negative central bank equity. From an orthodox perspective, a central bank's financial strength is key to preserving its credibility and political independence (Belke and Polleit, 2010; Sims, 2003). The reasoning is that the accumulation of losses will undermine the political independence of the central bank by making it reliant on fiscal authorities for recapitalization since 'one cannot rule out the possibility that the capital injection would come with special conditions attached constraining the central bank's activities' (Ernhagen et al., 2002: 6). However, this argument presupposes a priori that central bank recapitalization is required and overlooks the fact that a central bank cannot go bankrupt like a private institution as it can always absorb losses by creating outside money. Indeed, according to a less orthodox interpretation, rather than fiscal backing:

the only support a central bank needs is the political support of the sovereign that guarantees the legal tender nature of the money issued by the central bank... [I]t is quite ludicrous to believe that governments that can and sometimes do default are needed to provide the capital of an institution that cannot default. (De Grauwe, 2013: 526)

For this reason, the conceptual justification of central bank recapitalization should be challenged.

Are there any empirical reasons to necessitate central bank recapitalization? A few econometric studies of the potential monetary consequences of central bank losses found a negative relationship between the financial strength of the central bank and inflation outcomes (Klüh and Stella, 2008; Perera et al., 2013). Another econometric study showed that central bank financial strength can be a statistically significant factor explaining negative interest rate deviations from 'optimal' levels based on a forward-looking Taylor rule (Adler et al., 2012). Although, in theory, these potential monetary consequences could undermine the credibility and reputation of the central bank to maintain price stability, in actual practice, this occurs only in exceptional circumstances when its equity drops far below zero (Benecká et al., 2012). There was, therefore, no good reason to believe that potential losses would, in the medium (and even longer) term, have constrained the capacity of the ECB to keep inflation from spiralling out of control. In fact, it can be argued that upholding informal rules and policy norms whose only purpose could be to support the ECB's ability to pursue low inflation in all states of the economy was incongruous in light of the fact that 'chronic deflation' rather than 'chronic inflation' had become the key risk (Calvo, 2016). 


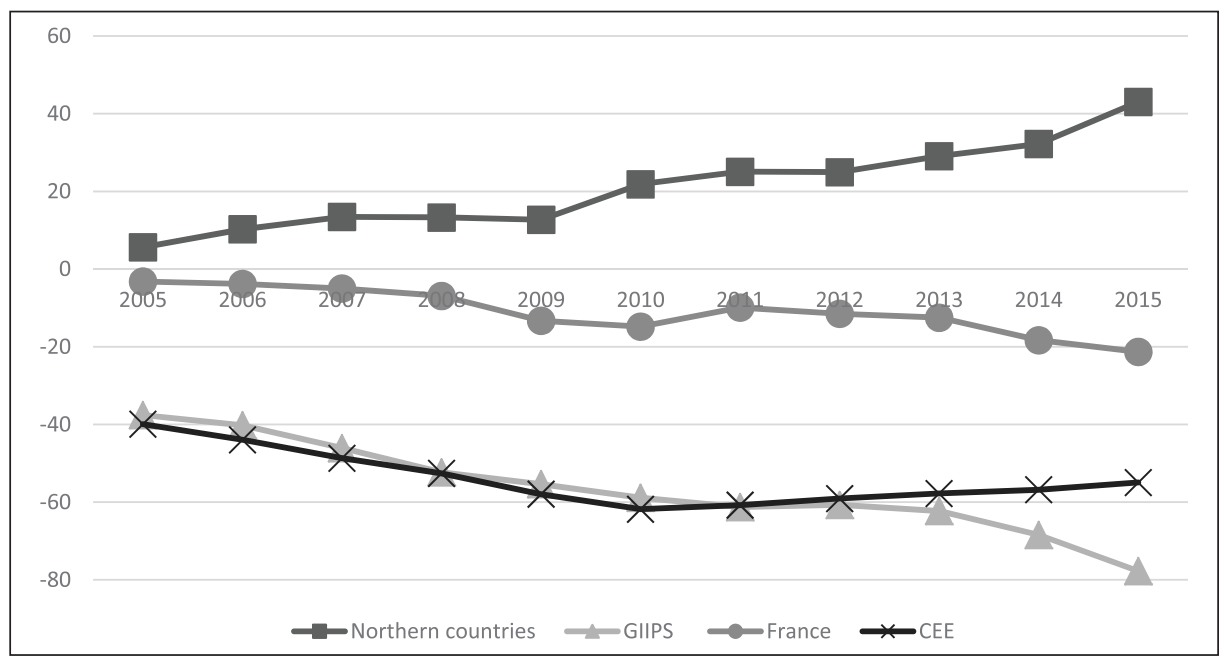

Figure 9. Net international investment position in \% of GDP.

Note: Country group averages were weighted according to the GDP shares of countries in the groups. Northern countries = Austria, Belgium, Finland, Germany, Luxemburg, Netherlands; GIIPS = Greece, Italy, Ireland, Portugal, Spain; CEE = Estonia, Latvia, Lithuania, Slovakia, Slovenia.

Source: Eurostat and author's calculations.

Hence, the ECB's concerns about the potential distributional fiscal effects of a balance-sheet expansion reveal a deflationary bias in its monetary policy that had important distributional consequences. As the ECB and the current EMU regime have consigned the northern and peripheral countries to, respectively, 'creditor' and 'debtor' status, as reflected by their net international investment position (NIIP) (see Figure 9), low inflation chiefly benefits the former countries by supporting the real value of the claims against the latter countries. This is intrinsically linked to trade imbalances: as discussed earlier, northern countries' export-oriented growth model led to current account surpluses, which resulted in foreign claims that were used to finance the current account deficits of domestic demand-led peripheral countries. This points to another key reason why the ECB's decisions advanced the interests of the northern Eurozone countries: low inflation strengthens the competiveness of the export-oriented sectors that play a central role in their economy (Vermeiren, 2017).

The fact that deflationary monetary policies bolster the export and creditor interests of the northern countries could imply that the ECB was wary about pursuing potentially inflationary policies that would undermine its political legitimacy in powerful countries like Germany. There is a strong difference between the Eurozone's creditor and debtor countries in the extent to which their citizens were concerned about economic indicators like inflation, government debt and unemployment: while citizens from creditor countries were generally more inflation-averse and cautious about the risks of growing public debt levels during the deepest phase of the euro crisis (2011-2012), those from debtor countries were much more concerned about high levels of unemployment (see Table 4). Even though its expansionary monetary policies have been too restrictive for the debtor 
Table 4. Most important issues for Eurozone voters (20II-20I3).

\begin{tabular}{|c|c|c|c|c|}
\hline & \multicolumn{2}{|c|}{$\begin{array}{l}\text { Most important issue facing the } \\
\text { country }\end{array}$} & \multicolumn{2}{|c|}{$\begin{array}{l}\text { Most important issue facing the } \\
\text { country }\end{array}$} \\
\hline & $\begin{array}{l}\text { Inflation/ } \\
\text { public debt }\end{array}$ & Unemployment & $\begin{array}{l}\text { Inflation/ } \\
\text { public debt }\end{array}$ & Unemployment \\
\hline Austria & 0.65 & 0.23 & 0.62 & 0.17 \\
\hline Belgium & 0.46 & 0.44 & 0.41 & 0.20 \\
\hline Germany & 0.62 & 0.22 & 0.66 & 0.12 \\
\hline Finland & 0.41 & 0.38 & 0.56 & 0.16 \\
\hline Netherlands & 0.23 & 0.32 & 0.54 & 0.13 \\
\hline France & 0.36 & 0.59 & 0.36 & 0.22 \\
\hline Greece & 0.33 & 0.58 & 0.24 & 0.36 \\
\hline Italy & 0.30 & 0.33 & 0.39 & 0.51 \\
\hline Portugal & 0.39 & 0.57 & 0.38 & 0.44 \\
\hline Spain & 0.46 & 0.44 & 0.19 & 0.45 \\
\hline
\end{tabular}

Source: Euroboarometer.

countries, the ECB is fully aware that these policies are politically contested in many creditor countries - especially in Germany. The ECB's OMT and QE decisions were opposed by the Bundesbank, which believed that sovereign debt purchases would reduce the pressure on debtor governments to implement fiscal and structural reforms and increased the ECB's exposure to debtor default (Steinberg and Vermeiren, 2016). These concerns gained widespread traction within German society, leading several politicians to submit a motion to the Federal Constitutional Court (FCC) to investigate the legality of the ECB's OMT and its QE program. The FCC reinforced these fears by claiming that the ECB's OMT and PSPP may violate the TFEU, deferring a definite ruling on the legality of these programmes to the European Court of Justice.

In sum, the ECB's deflationary bias might be indirectly related to the absence of a political union in the sense that the ECB was reluctant to pursue policies that would clearly be contested and seen as illegitimate in the creditor countries: the ECB pursued policies that accorded as much as possible with rules that prioritized the pursuit of price stability and prohibited fiscal transfers between Eurozone governments. However, by doing so, it interpreted these rules in an unduly restrictive way that privileged the interests of the creditor countries over those of the debtor countries. Indeed, as the former governor of the Central Bank of Cyprus rightly notes, the ECB enjoyed an 'unparalleled discretion and lack of accountability' in terms of deciding whether the public debt issued by a member state can qualify as collateral for its monetary policy operations and under which terms it can be included in an asset purchase programme:

In many cases, it could be argued that alternative discretionary decisions could have ensured more equal treatment for member states. However, the ECB had the discretionary power to change the rules as it saw fit during the crisis, with the result of benefiting some member states and discriminating against others. (Orphanides, 2016: 16-17; see also Woodruff, 2016) 
The ECB's reluctance to expose its balance sheet to peripheral sovereign debt was a political choice with important distributional implications rather than a simple application of TFEU rules that prohibit fiscal transfers; these rules contained more flexibility than assumed, suggesting that the ECB failed to act as a neutral mediator between creditor and debtor interests.

\section{Conclusion}

In this article, I have challenged a prevailing premise that international currency leadership needs to be based on conservative macroeconomic policy institutions and practices. The principal reason why prevailing theories on currency internationalization believe that this is the case is that such macroeconomic policy conservatism is assumed to be necessary to support foreign confidence in the stability of the currency's real value. By drawing on chartalist insights and scholarship on safe assets, I maintained that foreign confidence in the international currency's nominal safety is more important than foreign confidence in the stability of its real value: the international currency issuer must be the world's provider par excellence of safe assets whose nominal payment needs to be guaranteed and contain no default risk. In a world economy that is plagued by a scarcity of safe assets, international currency leadership should therefore be underpinned by accommodating macroeconomic policy institutions. First, an accommodating macroeconomic policy is central to the creation of safe assets: the central bank needs to provide a monetary backstop to the market for sovereign debt securities by acting as LLR to the government. Expansionary fiscal policy, on the other hand, is necessary to sufficiently expand the stock of the only securities that can secure safe asset status through such a monetary backstop: sovereign debt. Second, expansionary monetary and fiscal policies are critical for the provision of safe assets to the rest of the world: these policies lead to deficits on the current account balance by boosting domestic demand, which is necessary to allow the international currency issuer to become a net international seller of safe assets.

I have shown in this article that the Eurozone's monetary and fiscal policy nexus has constrained the region's capacity to meet the world's demand for safe assets. I did so by highlighting the role of the ECB's discretionary decisions as to when to produce highpowered outside money and how to allocate that money to private banks and governments - via defining the eligibility criteria for its liquidity facilities and controlling the launch and operational features of its asset purchase programmes. Its decisions favoured the creditor and export interests of the northern countries by producing a deflationary bias in the region and enabling the latter countries to deflect the burden of macroeconomic adjustment to the peripheral countries. Together with new stringent rules imposing fiscal austerity on Eurozone governments, the ECB's monetary policy choices intensified the global safe asset shortage by contributing to a growing aggregate current account surplus for the Eurozone, as a result of which, the region became a significant net international buyer of safe assets in the world economy. Furthermore, I argued that the ECB's decisions were not predetermined by the restrictive macroeconomic policy rules established by the TFEU, questioning a common interpretation that the lack of fiscal union and the ensuing need to avoid fiscal transfers constrained the ability of the ECB 
to treat fiscally strong and weak Eurozone governments in a more equal way. As such, the lack of a more accommodative monetary and fiscal policy nexus was more constraining to the region's ability to become a more important net international supplier of safe assets than the absence of fiscal union and the continuing segmentation of sovereign bond markets.

In sum, my analysis suggests that it is necessary to look beyond the lack of fiscal and political integration in order to understand the political constraints to the international status of the euro. While the presence of a fiscal and political union might be a necessary condition for the euro to rival the dollar as an international currency, it is by no means a sufficient one: change towards a more accommodative monetary and fiscal policy nexus would also be needed to offer a full guarantee of the safety of public debt and enable the region to accumulate the aggregate trade deficits required for its role as a net international safe asset supplier.

\section{Funding}

This research received no specific grant from any funding agency in the public, commercial or not-for-profit sectors.

\section{Notes}

1. In the US, the Federal Reserve's liquidity facilities provided public backstops even in some sectors of the private shadow banking system such as the repo market (Murrau, forthcoming).

2. As Posen (2008: 78) notes, seen from this angle, it is not a coincidence "that the Common Franc Area (CFA) franc zone, where France still intervenes militarily, is the only group of countries outside of Eurozone membership candidacy to peg to the euro, while those EU members with the strongest desire for independent security policies (Poland, Sweden and the United Kingdom) are the ones which have refused to enter the Exchange Rate Mechanism I in preparation for Eurozone membership'.

3. In some accounts like 'Modern Monetary Theory', fiscal deficits are even indispensable to inject high-powered money and liquidity in the economy. Wray (1998: 81) argues that 'persistent deficits are the expected norm' as 'taxes in the aggregate will have to be less than total government spending due to preferences of the public to hold some reserves of fiat money'.

4. Concerns about the 'unsustainability' of US fiscal deficits also explain why some scholars believe that the military preponderance of the US and its resulting geopolitical ambitions and responsibilities can, in the long term, undermine foreign confidence in the dollar (e.g. Calleo, 2009; Layne, 2012).

5. While it might be objected that interest rates on Spanish and Italian bonds were lower than the interest rates on 10-year US treasuries during most of this period, it should be noted that bond yields are determined by many different factors, including the output gap and expectations of future inflation. Since the output gap in the US has been consistently lower than in Spain and Italy and resulting (expectations of) inflation higher, it is not really surprising that nominal interest rates on US treasuries have been higher than those on Spanish and Italian sovereign bonds. What ultimately defines a genuinely safe asset is not the yield per se, but the movement of the yield during times of stress: 'safe assets generally benefit from a negative premium because holding them allows investors to hedge themselves partly against recessions, given their negative correlation with risky assets during crisis episodes in which risk aversion increases' (Claeys, 2016: 4). While this is the case for US treasuries and German bonds, Spanish and Italian bonds do not have this feature. 
6. It is important to note that the ECB's monetary policy response to the crisis has also favoured the traded sectors in the peripheral countries: they have benefited from the sharp reaction in ULCs and the depreciation of the euro (as Figure 8 shows; see also Vermeiren, 2017). Yet, traded sectors only play a minor role in the peripheral economies, which are more reliant on domestic demand centred around non-traded sectors. Therefore, peripheral countries (especially their highly indebted non-traded sectors) would have benefited from higher inflation and lower interest rates (hence more expansionary macroeconomic policies).

\section{References}

Acharya V and Steffen S (2013) The 'greatest' carry trade ever? Understanding Euro-zone bank risks. NBER Working Paper No. 19039.

Adler G, Castro P and Tovar C (2012) Does central bank capital matter for monetary policy? IMF Working Paper No. 12/60.

Andrews D (ed) International Monetary Power. Ithaca: Cornell University Press.

Armstrong A, Caselli F, Chadha J and den Haan W (2015) Risk-sharing and the effectiveness of the ECB's quantitative easing programme. VoxEU.org, 23 October.

Belke A and Polleit T (2010) How much fiscal backing must the ECB have? The Euro Area is not (yet) the Phillipines. Economie Internationale 4(124): 5-30.

Benecká S, Holub T, Kadlčáková N and Kubicová I (2012) Does Central Bank Financial Strength Matter for Inflation? An Empirical Analysis. CNB Working Paper Series 3/2012, Prague: Czech National Bank.

Bini Smaghi L (2009) The internationalization of currencies: A central bank perspective. In: Pisani-Ferry J and Posen A (eds) The Euro at Ten: The Next Global Currency? Washington, DC: Peterson Institute for International Economics.

Braun B (2015) Preparedness, crisis management and policy change: The euro erea at the critical juncture of 2008-2013. British Journal of Politics and International Relations 17(3): 419-441.

Caballero R and Farhi E (2014) The safe asset trap. NBER Working Paper No. 19927.

Caballero R, Farhi E and Gourinchas P (2008) An equilibrium model of global imbalances and low interest rates. American Economic Review 98(1): 358-393.

Calleo D (2009) Twenty-first century geopolitics and the erosion of the dollar order. In: Helleiner E and Kirshner J (eds) The Future of the Dollar. Ithaca, NY: Cornell University Press.

Calvo G (2016) From Chronic Inflation to Chronic Deflation: Focusing on Expectations and Liquidity Disarray Since WWII. NBER Working Paper No. 22535.

Carlin W and Soskice D (2009) German economic performance: Disentangling the role of supplyside reforms, macroeconomic policy and coordinated economy institutions. Socio-Economic Review 7(1): 67-99.

Chey H (2012) Theories of international currencies and the future of the world monetary order. International Studies Review 14(1): 51-77.

Chinn M and Frankel J (2008) Why the euro will rival the dollar. International Finance 11(1): 49-73.

Claeys G (2016) Low long-term rates: bond bubble or symptom of secular stagnation? Bruegel Policy Contribution No. 15.

Coeuré B (2016) Sovereign debt in the euro area: Too safe or too risky. Keynote Address at Harvard University's Minda de Gunzburg Center for European Studies in Cambridge, MA, 3 November.

Cohen BJ (1998) The Geography of Money. Ithaca, NY: Cornell University Press. 
De Grauwe P (2013) The European Central Bank as lender of last resort in the government bond markets. CESifo Economic Studies 59(3): 520-535.

De Grauwe P and Ji Y (2015) Quantitative easing in the Eurozone: It's possible without fiscal transfers. VoxEU.org, 15 January. http://voxeu.org/article/quantitative-easing-eurozone-itspossible-without-fiscal-transfers.

ECB (2010) Convergence Report. Frankfurt: European Central Bank.

Eichengreen B (2007) Global Imbalances and the Lessons of Bretton Woods. Cambridge: MIT Press.

Eichengreen B (2011) Exorbitant Privilege. Oxford: Oxford University Press.

Ernhagen T, Vesterlund M and Viotti S (2002) How much equity does a central bank need? Economic Review 2: 5-18.

Farhi E, Gourinchas P and Rey R (2011) Reforming the International Monetary System. London: Centre for Economic Policy Research.

Fields D and Vernengo M (2013) Hegemonic currencies during the crisis: The dollar versus the euro in a chartalist perspective. Review of International Political Economy 20(4): $740-759$.

Gabor D and Ban C (2016) Banking on bonds: The new links between states and markets. Journal of Common Market Studies 54(3): 617-635.

Germain R and Schwartz H (2014) The political economy of failure: The euro as an international currency. Review of International Political Economy 21(5): 1095-1122.

Goodhart C (1998) The two concepts of money: Implications for the analysis of optimal currency areas. European Journal of Political Economy 14: 407-432.

Gorton G, LeWellen S and Metrick A (2012) The safe asset share. American Economic Review 102(3): 101-106.

Gourinchas P and Jeanne O (2012) Global safe assets. Paper presented at the 11th BIS Annual Conference, 22 June.

Hager S (forthcoming) A global bond: Explaining the safe-haven status of US Treasury securities. European Journal of International Relations.

Helleiner E (2008) Political determinants of international currencies: What future for the US dollar? Review of International Political Economy 15(3): 354-378.

Helleiner E (2015) The future of the euro in a global monetary context. In: Blyth M and Matthijs M (eds) The Future of the Euro. Oxford: Oxford University Press.

Helleiner E and Kirshner J (eds) (2009) The Future of the Dollar. Ithaca, NY: Cornell University Press.

Henning R (2015) The ECB as a strategic actor: Central banking in a politically fragmented monetary union. In: Caporaso A and Rhodes M (eds) Europe's Crises: Economic and Political Challenges of the Monetary Union. New York, NY: Oxford University Press.

Högenauer A and Howarth D (2016) Unconventional monetary policies and the European Central Bank's problematic democratic legitimacy. Journal of Public Law/Zeitschrift für öffentliches Recht 71(2): 425-448.

IMF (2012) Global Financial Stability Report. Washington, DC: International Monetary Fund. Ingham G (2004) The Nature of Money. Cambridge: Polity Press.

Iversen T and Soskice D (2013) A structural-institutional explanation of the Eurozone crisis. Unpublished manuscript. Cambridge, MA: Harvard University, Department of Government.

Jarocinski M and Mackowiak B (2017) Monetary-fiscal interactions and the euro area's malaise. ECB Working Paper No. 2072.

Kirshner J (2008) Dollar primacy and American power: What's at stake? Review of International Political Economy 15(3): 418-438. 
Klüh U and Stella P (2008) Central Bank Financial Strength and Policy Performance: An Econometric Evaluation. IMF Working Paper 08/176, Washington: International Monetary Fund.

Landau JP (2013) Global liquidity: Public and private. Proceedings of the Federal Reserve Bank of Kansas City Economic Symposium at Jackson Hole.

Lavoie M (2011) The monetary and fiscal nexus of neo-chartalism: A friendly critical look. Mimeo.

Lavoie M (2015) The Eurozone crisis: a balance-of-payment problem or a crisis due to a flawed monetary design? International Journal of Political Economy 44(2): 57-60.

Layne C (2012) This time it's real: The end of unipolarity and the Pax Americana. International Studies Quarterly 56(1): 203-213.

Lucarelli B (2015) The Euro: A Chartalist critique. International Journal of Political Economy 44: $18-31$.

Ma G and Yao W (2013) Can the Chinese bond market facilitate a globalizing renminbi? BOFIT Discussion Papers. Helsinki: Bank of Finland

McNamara K (2008) A rivalry in the making? The euro and international monetary power. Review of International Political Economy 15(3): 439-459.

Murrau S (forthcoming) Shadow money and the public money supply: The impact of the 2007-2009 financial crisis on the monetary system. Review of International Political Economy.

Norrlof C (2010) America's Global Advantage: US Hegemony and International Cooperation. Cambridge: Cambridge University Press.

Norrlof C (2014) Dollar hegemony: A power analysis. Review of International Political Economy 21(5): 1042-1070.

Obstfeld M (2013) The international monetary system: Living with asymmetry. In: Feenstra R and Taylor R (eds) Globalization in an Age of Crisis: Multilateral Economic Cooperation in the Twenty-First Century. Chicago, IL: Chicago University Press.

Orphanides A (2016) The fiscal implications of central bank balance sheet policies. Mimeo.

Orphanides A (2017) The fiscal-monetary policy mix in the euro area: Challenges at the zero lower bound. Mimeo.

Otero-Iglesias M (2014) The Euro, the Dollar and the Global Financial Crisis: Currency Challenges Seen from Emerging Markets. New York, NY: Routledge.

Otero-Iglesias M (2015) Stateless euro: The euro crisis and the revenge of the chartalist theory of money. Journal of Common Market Studies 53(2): 349-364.

Otero-Iglesias M (2017) Still waiting for Paris: Germany's reluctant hegemony in pursuing political union in the Euro Area. Journal of European Integration 39(3): 349-364.

Otero-Iglesias M and Steinberg F (2013) Reframing the euro vs. dollar debate through the perceptions of financial elites in key dollar-holding countries. Review of International Political Economy 20(1): 180-214.

Otero-Iglesias M and Zhang M (2013) EU-China collaboration in the reform of the international monetary system: Much ado about nothing? The World Economy 37(1): 151-168.

Paris P and Wyplosz C (2014) The PADRE plan: Politically Acceptable Debt Restructuring in the Eurozone. VoxEU.org, 28 January. http://voxeu.org/article/padre-plan-politically-acceptabledebt-restructuring-eurozone.

Perera A, Ralston D and Wickramanayake J (2013) Central Bank financial strength and inflation: is there a robust link? Journal of Financial Stability 9(3), 399-414.

Posen A (2008) Why the euro will not rival the dollar. International Finance 11(1): 75-100.

Rochon L and Vernengo M (2004) State money and the real world: Or chartalism and its discontents. Journal of Post-Keynesian Economics 26(1): 57-67. 
Schwartz H (2017) International money after the crisis: What do we know? In: Pixley J (ed.) Critical Junctures in Mobile Capital. Cambridge: Cambridge University Press.

Sims C (2003) Fiscal Aspects of Central Bank Independence. Unpublished manuscript, Princeton, New Jersey: Princeton University.

Soskice D (2007) Macroeconomics and varieties of capitalism. In: Hancké B, Rhodes M and Thatcher M (eds) Beyond Varieties of Capitalism: Conflicts, Contradictions, and Complementarities in the European Economy. New York, NY: Oxford University Press, pp. 89-121.

Steinberg F and Vermeiren M (2016) Germany's institutional power and the EMU regime after the crisis: Towards a Germanized euro area? Journal of Common Market Studies.

Stokes D (2014) Achilles' deal: Dollar decline and US grand strategy after the crisis. Review of International Political Economy 21(5): 1071-1094.

Tcherneva PR (2005) The nature, origins, and role of money: broad and specific propositions and their implications for policy. Working Paper 46, Center for Full Employment and Price Stability, Kansas City, MO.

Vermeiren M (2017) One-size-fits-some! Capitalist diversity, sectoral interests and monetary policy in the euro area. Review of International Political Economy 24(6): 929-957.

Walter A (2006) The domestic sources of international monetary leadership. In: Andrews DM (ed.) International Monetary Power. Ithaca, NY: Cornell University Press, pp. 51-71.

Woodruff D (2016) Governing by panic: The politics of the Eurozone crisis. Politics \& Society 44(1): 81-116.

Wray R (1998) Understanding Modern Money. Cheltenham: Edward Elgar.

Wray R (2014) Outside money: The advantages of owning the magic porridge pot. Levy Institute of Economics Working Paper No. 821.

\section{Author biography}

Mattias Vermeiren is Assistant Professor of International Political Economy at the Ghent Institute for International Studies, Ghent University, Belgium. He is the author of Power and Imbalances in the Global Monetary System: A Comparative Capitalism Perspective (Palgrave, 2014) and coauthor of Rising Powers and Economic Crisis in the Euro Area (Palgrave, 2016). 